\title{
SECURITIES EXCHANGE ACT OF 1934: PRIVATE INVESTOR HAS PRIVATE RIGHT OF ACTION UNDER SECTION I4(a)
}

$\mathrm{I}_{\mathrm{N}}$ the recent case of Dann v. Studebaker-Packard Corp., ${ }^{1}$ the Court of Appeals for the Sixth Circuit held that Section 14(a) of the Securities Exchange Act of $1934,{ }^{2}$ implemented by rule $\mathrm{X}-\mathrm{I} 4 \mathrm{~A}-9,{ }^{3}$ creates a substantive federal right in a private investor to enjoin the use of fraudulently solicited proxies.

Plaintiffs, stockholders in Studebaker-Packard Corporation, brought suit in their own behalf and in behalf of shareholders similarly situated against the company and individual directors, alleging defendants had fraudulently solicited proxies in violation of the Securities Exchange Act of $1934,{ }^{4}$ and had made an inaccurate count and report of the votes

${ }^{2} 288$ F.2d 20 (6th Cir. I96r).

3 "It shall be unlawful for any person, by use of the mails or by any means or instrumentality of interstate commerce or of any facility of any national securities exchange or otherwise to solicit or to permit the use of his name to solicit any proxy or consent or authorization in respect of any security ... registered on any national securities exchange in contravention of such rules and regulations as the Commission may prescribe as necessary or appropriate in the public interest or for the protection of investors." 48 Stat. 895 (1934), I5 U.S.C. $\$ 78$ n (1958).

8 "No solicitation... . shall be made by means of any proxy statement, form of proxy, notice of meeting, or other communication, written or oral, containing any statement which, at the time and in light of the circumstances under which it is made, is false or misleading with respect to any material fact, or which omits to state any material fact necessary in order to make the statements therein not false or misleading or necessary to correct any statement in any earlier communication with respect to solicitation of a proxy for the same meeting or subject matter which has become false or misleading." SEC Reg. 14, I7 C.F.R. \$ 240.14a-9 (Supp. 1960).

-Plaintiffs charged that the individual defendant directors fraudulently solicited Studebaker-Packard stockholders' proxies through the United States mails by means of false and misleading statements with respect to material facts and by omitting to state material facts necessary to make the statements not false and misleading. Brief for Appellants, pp. 4, 6a-7a.

Defendants' representations allegedly misled shareholders into believing that a merger of Curtis-Wright and Studebaker-Packard resources was planned which would yield additional hundreds of millions of dollars in new government contracts; and that there would be a preservation of Studebaker-Packard assets coupled with an opening of greater opportunities in the fields of aerophysics, guided missiles, and electronics. Studebaker-Packard's cost-plus government contracts were reported to be unprofitable, and the lack of shareholder information concerning its subsidiary, the 
cast at the stockholders' meeting at which certain management proposals were approved. ${ }^{5}$ The complaint sought a recount of the votes cast for the proposals, rescission of resulting consummated transactions, ${ }^{\circ}$ and damages for injuries sustained from those transactions. ${ }^{7}$ The disstrict court sustained defendants' motion to dismiss in which they contended, inter alia, ${ }^{8}$ that plaintiffs' complaint failed to state a claim upon which relief could be granted.

On appeal, the first question faced by the court was whether the Securities Exchange Act had created a private federal right which plaintiffs had standing to assert. ${ }^{9}$ The general provisions of the act afford

Aerophysics Corporation, made it impossible to determine whether an adequate price was to be paid. The plaintiffs further claimed that the material misrepresented that shareholders would have preemptive rights to new issue shares, and that StudebakerPackard's former president had forfeited all his rights to salary and settlement. Brief for Appellants, pp. 8-12.

"The proposals allegedly sought stockholder endorsement for certain "arrangements" with the Curtis-Wright and Utica-Bend Corporations which included assigning contracts, selling and leasing property, offering a stock option, and securing management assistance. See note 6 infra. Plaintiffs charged that while management's proposals required two-thirds approval of outstanding shares, they received less than fifty percent of the vote. Passage of the proposals, plaintiffs claimed, was due to individual defendants' failure to properly inspect the proxies. Brief for Appellants, pp. 8-9.

${ }^{-A s}$ a result of the allegedly fraudulent solicitations, plaintiffs claimed defendant corporation (I) assigned all its government contracts valued at $\$ 70,000,000$ to CurtisWright; (2) transferred its accumulated assets in the Aerophysics Corporation to Curtis-Wright without any inventory, appraisal, or adequate consideration; (3) granted an option to Curtis-Wright to purchase millions of dollars of Studebaker-Packard stock at $\$ 5$ per share; and $(4)$ submitted to management by Curtis-Wright under the guise of an Advisory Management Agreement whereby Studebaker-Packard directors surrendered their right to independent action. Brief for Appellants, pp. 8-9.

${ }^{7}$ Plaintiffs charged that the agreements did not yield a merger of assets and facilities, did not enable Studebaker-Packard to obtain a large volume of government contracts, and resulted in a sale of the Aerophysics subsidiary to Curtis-Wright at a grossly inadequate price. Moreover, it was claimed that the stock option granted to CurtisWright overrode the shareholders' right of preemption; and that contrary to the implication that Studebaker-Packard's former president had forfeited his salary and settlement benefits, he had, in fact, continued to enjoy both. Brief for Apellants, pp. 5-10.

${ }^{8}$ Defendants' motion was ' $\mathrm{x}$. The District Court lacked jurisdiction over the subject matter ... and/or 2. The amended complaint failed to state a claim upon which relief could be granted, and/or 3. The amended complaint failed to comply with the mandatory requirements of Fed. R. Civ. P. $23(a)$ and (b) ... and/or 4. The plaintiffs ... failed to join indispensible parties. .." $288 \mathrm{~F} .2 \mathrm{~d}$ at 205 . The district court gave no indication which of the grounds it relied upon for dismissal. Ibid.

- Only two cases had previously considered the question of an express private right under the section. Howard v. Furst, 140 F. Supp. 507, 510, 512 (S.D.N.Y.), 238 
investors in securities protection against market manipulation, while the specific provisions of section $\mathrm{I} 4$ (a) control conditions under which proxies may be solicited. ${ }^{10}$ The court found 'that the federal 'right' sought to be protected by this section of the Act is the stockholders' right to full and fair disclosure in corporate elections by proxy."

F.2d 790, 793 (2d Cir. 1956), cert. denied, 353 U.S. 937 (1957) (question of a private right left open on appeal); Subin v. Goldsmith, 224 F.2d 753, 765 (2d Cir.) (dissenting opinion), cert. denied, 350 U.S. $88_{3}$ ( 1955 ).

Although no previous case had formally defined the existence of a private right of action, several cases had implied the existence of some right. The first case to recognize any private right of action was Tate v. Sonotone Corp., 5 SEC Jud. Dec. 3 IQ (S.D.N.Y. 1947), where the court without opinion issued a two-week restraining order upon petition by a shareholder to enjoin the corporation from holding its annual meeting until the management had complied with the proxy rules. In Phillips v. United Corp., 5 SEC Jud. Dec. 445 (S.D.N.Y. 1947), a qualified private right of action was recognized when the SEC failed to act after a shareholder's request. There a stockholder sought to enjoin a registered holding company from action to effect its transformation into an investment company because the proxies approving the transformation were allegedly obtained in violation of $\S \mathrm{I}_{4}(\mathrm{a})$. See cases collected in Loss, The SEC Proxy Rules in the Courts, 73 HARV. L. REV. 104.1, 1046 n.15 (1960), in 2 Loss, Securities Regulation 933 n.289 (2d ed. 1961).

${ }^{10}$ See Stock Exchange Practices, Hearings before the Senate Committee on Banking and Currency on S. Res. 84, 72d Cong., and S. Res. $5^{6}$ and S. Res. 97, 73d Cong., Ist \& 2d Sess. (1932-34); H.R. REP. No. 1383 , 73d Cong., 2d Sess. 2-5 (1934); S. Rep. No. 792, 73d Cong., 2d Sess. 3-5 (1934). The Senate report indicates Congressional feeling that "the rules and regulations promulgated by the Commission will protect investors from promiscuous solicitation of their proxies, on the one hand by irresponsible outsiders seeking to wrest control of the corporation away from honest and conscientious officials; on the other hand by unscrupulous corporate officials seeking to retain control of the management by concealing or distorting facts." S. REP. No. 1455, 2d Sess. 77 (1934). Accord, SEC v. May, 229 F.2d 123, 124 (2d Cir. 1956); SEC v. Transamerica Corp., 163 F.2d 511, 518 (1947), cert. denied, 332 U.S. 847 (1948) (found intent of Congress was to require fair operation of corporate sufferage).

${ }_{11} 288$ F.2d at 208 . Neither $\S 14$ (a) nor rule X-14A-9 provide for a private civil remedy as do three sections of the act, e.g., $\S 9(\mathrm{e}) ; \S 16(\mathrm{~b}) ; \S$ I8. It is well settled, however, that courts will recognize a civil cause of action in tort if the violation of a criminal statute injures a member of the class whose interests the statute was enacted to protect. See SEC v. Joiner Corp., 320 U.S. 344, 350-51 (1943) (to effect that the maxim expressio unius est exclusio alterius is subordinate to the general purpose of the act); Slavin v. Germantown Fire Ins. Co., 174 F.2d 790, 805 \& n.12 (3d Cir. 1949); see generally Latty, The Aggrieved Butyer or Seller or Holder of Shares in a Close Corporation Under the S.E.C. Statutes, 18 LAW \& CoNTEMP. ProB. 505, 512 (1953).

A "right," therefore, was recognized even as to plaintiffs whose proxies were not claimed to have been solicited. Contra, Textron, Inc. v. American Woolen Co., 122 F. Supp. 305 (D. Mass. 1954); Commonwealth ex rel. Laughlin v. Green, 4 SEC Jud. Dec. 14 I ( $\mathrm{Pa}$. C.P. 1944), aff'd without mention of proxy rules, 35 I $\mathrm{Pa}$. I70, 40 A.2d 492 (1945). 
point the court had to reconcile the recent Second Circuit decision in Howard v. Furst ${ }^{12}$ that section I4(a) does not create a right of action in the corporation which the shareholder can assert derivatively under federal law. The court distinguished Howard by noting that the question in Dann dealt with invasion of the individual shareholder's right of franchise rather than damages to the corporation. ${ }^{13}$ Since the right of franchise is individual, Howord was held to be inapplicable.

Having found a federal right which plaintiffs had standing to assert, the court turned to consideration of the remedy available. Here two conflicting approaches were encountered. One would recognize complete federal jurisdiction to dispose of all issues raised in the pleadings; ${ }^{14}$ the other would restrict jurisdiction to a determination of whether a federal right had been violated. ${ }^{15}$ To have allowed complete federal jurisdiction in Dann would necessarily have involved determina-

\footnotetext{
${ }^{12} 238$ F.2d 790 (2d Cir. 1956), cert. denied, 353 U.S. 937 (1957), 70 Harv. L. REv. 1493 (1957), 105 U. PA. L. REv. 1016 (1957). A shareholder brought a derivative action against corporate directors to enjoin voting of proxies allegedly obtained through fraudulent statements. Dismissal of the complaint was upheld on the gruund that the act did not create substantive rights for the benefit of the corporation. 238 F.2d at 793 .

${ }^{1 s}$ One of the main obstacles presented by the Howvard case was its holding that although a shareholder may claim to assert an individual right, in reality, since the damages he suffers are secondary to him through injury to the corporation, his assertion is basically on behalf of the corporation. Ibid. The court, in a candid admission, avoided this pitfall by stating: "Of course, the general rules [concerning whether an injury is derivative or individual] . . . , in the last analysis, are merely legal formalisms in which the Court elects to clothe its choice of the underlying policy considerations upon which the real basis of decision must rest. In characterizing this action as 'derivative' or as 'individual,' basically we are faced with the problem of determining whether to emphasize the right violated, or the damage which resulted. In this case, we choose to lay emphasis upon the right violated, which is individual and primary." 288 F.2d at $2 \mathrm{r}$.

11 The doctrine that for every federal right there is a federal remedy is generally attributed to Bell v. Hood, 327 U.S. 678, 684-85 (x946). Support has been given to complete federal jurisdiction in cases arising under $\S 1_{4}(a)$ of the Exchange Act. See, e.g., Mack v. Mishkin, 172 F. Supp. 885 (S.D.N.Y. 1959); Horwitz v. Balaban, 112 F. Supp. 99 (S.D.N.Y. 1949); cf. Baird v. Franklin, 141 F.2d 238 (2d Cir.), cert. denied, 323 U.S. 737 ( 1944 ). This position has long been advocated by Professor Loss in his exhaustive works on the subject. See generally Loss, The SEC Proxy Rules in the Courts, 73 HARV. L. REv. 1041, 1045-58 (1960), in 2 Loss, Securities Regulation 932-73 (2d. ed. x961). The Securities Excbange Commission also favors complete federal jurisdiction. Bricf for the SEC on appeal to the 9th Cir. as Amicus Curiae from the decision in Sawyer v. Pioneer Mill Co., Ltd., 190 F. Supp. 2 (D. Hawaii 196r).

${ }^{15}$ Howard v. Furst, 140 F. Supp. 507, $5^{13}$ (S.D.N.Y. 1956).
} 
tion of the parties' rights with respect to the effects of the alleged invalidity of the proxies. The majority of the court opposed this because they felt that determination of effects would primarily involve issues of state law to which the federal claim would be only "collateral."16 Restricted jurisdiction, on the other hand, would have encouraged piecemeal litigation, a result which the court equally opposed.

In effect the court adopted a combination of the two approaches, holding that a private investor who has standing to assert a federal right of action because of violation of section I4(a) may be granted prospective relief. This holding restricts federal jurisdiction to determination of the validity of proxies solicited and affords injunctive protection up until the time the proxy is exercised; thereafter relief is limited to a declaratory judgment as to the validity of the proxies. The court reasoned that this was "the cleanest joint at which to amputate the long arm of federal law in this area"17 and that prevention is the best cure for "injection of misleading statements into a proxy fight." Since the proxies in the instant case had long since been voted, ${ }^{19}$ plaintiffs were left without effective federal relief. However, plaintiffs had concurrently initiated a derivative suit in a Michigan state court ${ }^{20}$

${ }^{10} 288$ F.2d at 215 . The court could have granted complete relief by assuming pendent jurisdiction. This was rejected, however, because of failure to meet the test of Hurn v. Oursler, 289 U.S. 238 (r933), that "substantially identical facts" must "support both the local and federal theories of recovery." The court said that "more facts are necessary to support a recission [sic] of the election under state law than ... to establish the fact that the proxies . . . were solicited by the use of false and misleading material." 288 F.2d at 215 . But see Errion v. Connell, 236 F.2d 447 (9th Cir. 1956). There pendent jurisdiction was granted in an action under $\S$ Io(b) where both the state and the federal actions were held to have arisen out of the same set of facts, i.e., fraud. The court said that "the thought of requiring two law suits in the situation is untenable." Id. at 454 .

The concurring opinion in Dann endorsed the complete jurisdiction approach, but joined the majority on the ground that rescission was correctly denied below on the merits either because the statute did not include retrospective relief, or in the alternative, because of the equities of the case. 288 F.2d at 218 .

${ }^{17} 288$ F.2d at 214 .

${ }^{18} 288$ F.zd at $2 \times 1$. Query whether this truism is as valid as the court would assert. Certainly the threat of civil liability after the election would serve to put teeth into the prohibitory sanctions of the statute. See, e.g., Mosser v. Darrow, 34r U.S. 267,274 ( $195 \mathrm{x})$, where the Court said that "the most effective sanction for good administration is personal liability for the consequences of the forbidden acts. . ."."

${ }^{10}$ The proxies were voted at the shareholders' meeting held on October $31,1956$. 288 F.2d at 205.

${ }^{30}$ Fong v. Studebaker-Packard Corp., $\#_{17} 821$. 
which sought relief "predicated upon the vote . . . and . . . representations in the proxy material. ${ }^{\prime 21}$ If the state court viewed the two actions as the same, the concurrent state suit would toll the Michigan statute of limitations.2 Thus an affirmative federal decree might be the basis for restrospective relief in the state court.

In the past, the usual remedy for violation of section 14 (a) has been petition by the Securities Exchange Commission to the federal courts for injunction, ${ }^{23}$ although in some instances criminal prosecution has been instituted against willful violators. ${ }^{24}$ Petitions for injunction have normally been filed by the Commission on its own initiative and, occasionally, in response to a shareholder's request. Since the SEC is not bound to act upon the individual shareholder's request, ${ }^{25}$ and since until Dann no private federal right under section $14(a)$ had been expressly recognized, ${ }^{26}$ an aggrieved shareholder has been without reliable individual remedy for an alleged violation of the federal proxy rules. Neither has the private investor had the right to institute a derivative proceeding in a federal court on behalf of the corporation. ${ }^{27}$ Furthermore, state courts have unanimously refused to take jurisdiction in any suit based upon violation of the Securities Exchange Act of I934 because of its exclusive federal jurisdiction provision. ${ }^{28}$ The private

\footnotetext{
22-Reply Brief for Appellants, p. 26.

${ }^{82}$ The Michigan statute of limitations for action against directors for breach of duties is either six years from the date of the delinquency, or two years from the time the complainant discovered the delinquency, whichever is the sooner. Мrсн. Comp. LAws. $\$ 450.47$ (1948). See generally 54 C.J.S. Limitation of Actions $\S 26 \mathrm{x}$ (1948, Supp. 1961), to the effect that commencement of an action will suspend the running of the statute as to that specific claim asserted in the action.

${ }^{23}$ Securities Exchange Act of $1934 \$ 21(\mathrm{e}), 48$ Stat. 899 (1934), as amended, 15 U.S.C. $\S 78 \mathrm{u}(\mathrm{e})(1958)$. In most instances an affirmative or negative injunction has served as sufficient means by which to control proxy solicitation. See Loss, The SEC Proxy Rules in the Courts, 73 HARv. L. REv. 1041, 1068-83 (1960), in 2 Loss, Securities Regulation 956-71 (2d ed. 1961).

${ }^{24}$ Securities Exchange Act of $1934 § 32,48$ Stat. 904 (1934), as amended, 15 U.S.C. \& $78 f$ (1958). Very few criminal prosecutions have been instituted for violation of the proxy rules; in fact, there are none on record prior to 1960 . See 3 Loss, Securities Regulation $1984-2004$ \& n.59 (2d ed. 1961).

${ }^{2 \pi}$ See, e.g., Phillips v. United Corp., 5 SEC Jud. Dec. 445 (S.D.N.Y. 1947), where the SEC refrained from acting after a shareholder had submitted his grievance.

${ }^{26}$ See note 9 supra.

${ }^{27}$ Howard v. Furst, 238 F.2d 790 (2d Cir. 1956). See S. REP. No. 792, 73d Cong., 2d Sess. 23 (1934) 378 Cong. Rec. 8099 (1934).

${ }^{28}$ Section 27 of the act vests exclusive jurisdiction in the federal courts of any "violations of this chapter or the rules and regulations thereunder, and of all suits in equity and actions at law brought to enforce any liability or duty created by this chapter
} 
investor, therefore, has been left without a remedy, save petition to the SEC requesting action, for violation of a federal statute admittedly enacted for his protection. In essence, the holding in Dann endows the private investor with the same power of injunction which has been effectively employed by the SEC.

In some respects Dann may be viewed as an important breakthrough in the direction of granting a complete federal remedy for violations of the proxy rules of the Exchange Act. Although several federal courts have endorsed by dictum an extension of federal relief available under section I4(a) to include retrospective remedies, no case has yet combined recognition of a private right with an award of retrospective relief. ${ }^{29}$ The act itself does not declare that action taken at a meeting pursuant to proxies obtained in violation of section I4(a) will be invalid. ${ }^{30}$ Nevertheless, proponents of such relief would infer such a provision by implication. ${ }^{31}$ Support for this position might be found

or the rules and regulations thereunder." 48 Stat. 902 (1934), as amended, 15 U.S.C. $\S 78 \mathrm{aa}$ (1958). Accord, In re R. Hoe \& Co., 137 N.Y.S.2d 142 (Sup. Ct. 1954), aff'd, 285 App. Div. 927, I39 N.Y.S.2d 883, aff'd, 309 N.Y. 7 I9, 128 N.E.2d 420 (I.955); Eliasberg v. Standard Oil Co.; 23 N.J. Super. 43I, 92 A.2d 862 (Ch. I952), aff'd, 12 N.J. 467, 97 A.2d 437 (1953); Investment Associates, Inc. v. Standard Power \& Light Corp., 29 Del. Ch. 225, 48 A.2d 501 (Ch. 1946), aff'd, 29 Del. Ch. 593, 5 I A.2d 572 (Sup. Ct. 1947); American Distilling Co. v. Brown, 295 N.Y. 36, 64 N.E.2d 347 (1945); but $c f$. Wyatt v. Armstrong, 186 Misc. 216,59 N.Y.S.2d 502 (Sup.. Ct. I945); Levy v. Feinberg, 29 N.Y.S.2d 550 (Sup. Ct. 1941), rev'd on other grounds, 265 App. Div. 208, 38 N.Y.S.2d. 517 (1942). See generally Loss, The SEC Proxy Rules and State Law, 73 Harv. L. Rev. 1249 (1960), in 2 Loss, Securities REgulation 973-1019 (2d ed. 1961).

${ }^{20}$ In Horwitz v. Balaban, 112 F. Supp. 99, 103 (S.D.N.Y. 1949), the court said that failure to comply with $\S 14(a)$ would render a contract for a stock conversion option void. Accord, Mack v. Mishkin, 172 F. Supp. 885, 889 (S.D.N.Y. 1959); Textron, Inc. v. American Woolen Co., 122 F. Supp. 305, 308 (D. Mass. 1954); cf. Weeks v. Alpert, 13 I F. Supp. 608 (D. Mass. I954); Curtin v. American Tel. \& Tel. Co., 124 F. Supp. 197 (S.D.N.Y. 1954); Dunn v. Decca Records, Inc., 120 F. Supp. I (S.D.N.Y. 1954); Doyle v. Milton, 73 F. Supp. 28 I (S.D.N.Y. 1947). See generally Loss, The SEC Proxy Rules in the Courts, 73 HARV. L. REv. 104I, 1068-85 ( 1960 ), in 2 Loss, Securities Regulation.956-73 (2d ed. 1961).

${ }^{30}$ The Commission does not favor an ipso facto doctrine of proxy invalidity for any violation; rather, it is felt, the legal effect of non-compliance with the proxy rules is for court determination. Accord, Textron, Inc. v. American Woolen Co., supra note 29. For background see Loss, The SEC Proxy Rules in the Courts, 73 Harv. L. REv. $1041,1072-85$ \& n.127 (1960), in 2 Loss, SECURITIES REGULATION 960-73 \& n.407 (2d ed. Ig6I).

${ }^{81}$ Securities Exchange Act of $1934 \S 29,48$ Stat. 903 (1934); as amended, 15 U.S.C. $\S 78 \mathrm{cc}$ (1958), provides that "(b) Every contract made in violation of any provision ... shall be void. ..." Thus it is argued that since violation of $\S 1_{4}(\mathrm{a})$ 
in cases arising under similar sections of the Exchange Act which are also solely prohibitory on their face, but from which courts have inferred authority to grant civil relief, including rescission of completed transactions. ${ }^{32}$

There are some important procedural advantages to the shareholder-claimant implicit in complete federal jurisdiction. Primarily they are elimination of piecemeal litigation; expeditious disposition of claims; and availability of broad venue, ${ }^{33}$ nation-wide service of process, ${ }^{84}$ liberal pleading requirements, ${ }^{35}$ and lenient amendment policies. ${ }^{36}$ On the other hand, certain policy considerations militate against complete federal jurisdiction. The primary role of the federal judiciary would change from assisting the SEC in controlling proxy solicitation by issuance of injunctions, to being an active participant serving as a

voids the proxy contract, the vote of the void proxy is nugatory. See, e.g., Goldstein v. Groesbeck, 142 F.2d 422 (2d Cir. 1944); Geismar v. Bond \& Goodwin, Inc., 40 F. Supp. 876 (S.D.N.Y. 194I).

"See Hooper v. Mountain States Securities Corp., 282 F.2d 195 (5th Cir. 1960) (§ 1o(b)); Errion v. Connell, 236 F.2d 447 (9th Cir. 1956) (§ 10(b)); Baird v. Franklin, 14I F.2d 238 (2d Cir.), cert. denied, 323 U.S. 737 (1944) (\$ 6(b)); Osborne v. Mallory, 86 F. Supp. 869 (S.D.N.Y. 1949) (§ 15(c)(I)); Hawkins v. Merrill, Lynch, Pierce, Fenner \& Beane, 85 F. Supp. I04 (W.D. Ark. 1949) (\$§ II (d) (2) and I7(a)); Remar v. Clayton Securities Corp., 8I F. Supp. ror4 (D. Mass. 1949) ( $(7$ (a)-(d)); Kardon v. National Gypsum Co., 73 F. Supp. 798 (E.D. Pa. 1947) ( $\S$ ro(b)). Section $10(\mathrm{~b})$, it should be noted, is distinguishable from $\S \mathrm{I}_{4}(\mathrm{a})$ in that it prohibits the use of fraudulent devices to effect the sale or purchase of securities. Civil damages naturally follow when the prohibited event occurs. Section $14(\mathrm{a})$, however, prohibits fraudulent solicitation of the proxy and not its use.

"Action may be brought in the district court where the defendant "is found or is an inhabitant or transacts business. ..." Securities Exchange Act of $1934 \$ 27,48$ Stat. 903 (1934), as amended, 15 U.S.C. $\$ 7822$ (1958). See United States v. Olen, 183 F. Supp. 212 (S.D.N.Y. 1960) (action brought in the district where corporate books were kept); Greenwich Sav. Bank v. Shields, 131 F. Supp. 368 (S.D.N.Y. 1955) (venue proper where misrepresentation made).

st "[P]rocess ... may be served in any . . . district of which the defendant is an inhabitat or wherever the defendant may be found." Securities Exchange Act of I $934 § 27$, supra note 33. See Thiele v. Shields, I3x F. Supp. 416 (S.D.N.Y. 1955) (defendants served with process in Nebraska for action in New York).

${ }^{25}$ See generally Clark, Simplified Pleading, 2 F.R.D. 456 (1943); 2 MOORE, Federal Practice If 8.14 (2d ed. 1953, Supp. I960); but see Buery v. Buery, 127 F. Supp. 786 (S.D.W. Va. 1954), where an allegation of fraud on the part of 3 corporation president in manipulating stock transactions to his own benefit was held insufficient to state a cause of action.

${ }^{83}$ See Fed. R. Civ. P. is(a); iA Barron \& Holtzoff, Federal Practice and Procedure $\$ \S$ 441-45 (1960, Supp. 1960); Clark, The Bar and The Recent Reform of Procedure, 25 A.B.A.J. 22 (1939). 
forum for any shareholder's petition for restrospective civil relief based upon an alleged violation of the proxy rules. This would make of the federal courts easily accessible forums for individual harassment or nuisance suits against the corporation and its directors, without effective means of protecting the defendants from mala fide claims. ${ }^{37}$ Also, federal courts would have either to determine what effect state law would give to proxies declared invalid under section $\mathrm{I} 4(\mathrm{a})$ or formulate federal law in this area.

The court, therefore, achieved a fairly successful compromise of conflicting policy considerations by rejecting pendent jurisdiction ${ }^{38}$ and restricting the scope of the newly recognized private federal "right" to prospective relief. In effect, the court accomplished a dual result. It combined formal recognition of a private right under the act with an effective instrument of prevention, while at the same time it forestalled the prospect of harassment and nuisance suits. Secondly, while adjudication of a claimant's federal right was granted, an extension of federal jurisdiction into matters of state corporation law was ostensibly avoided by leaving determination of the effect of proxy invalidity to the state courts.

The rule in Dann provides the aggrieved private investor two channels for relief. Prior to the proxy election, it is clear that federal courts may grant injunctive relief for a violation of section I $_{4}(\mathrm{a})$. It would seem that a declaratory judgment as to the validity of the proxies under federal law would also be proper at this time. Before the elec-

\footnotetext{
${ }^{s t}$ It is generally the rule that a suit brought by a shareholder against directors or officers who have defrauded or mismanaged a corporation, thus affecting share values, is derivative in nature, and the shareholder is considered to have no direct individual right of action. Smith v. Bramwell, 146 Ore. 6x1, 31 P.2d 647 (1934); Ballantine, Corporations 333 (rev. ed. 1946). In such derivative actions. Fed. R. Civ. P. 23(b) requires that "the complaint shall be verified by oath and shall aver ... (2) that the action is not a collusive one to confer on the court of the United States jurisdiction of any action of which it would not otherwise have jurisdiction. The complaint shall also set forth with particularity the efforts of the plaintiff to secure from the managing directors or trustees and, if necessary, from the shareholders such action as he desires, and the reasons for his failure to obtain such action or the reasons for not making such effort."

In an individual action such limitations and restrictions are not required. Of course, FED. R. CIV. P. I I provides that claimant's attorney must certify "that to the best of his knowledge, information, and belief there is good ground to support [the claim]...." However, any technical breach of the Exchange Act could serve as "good ground" to support a mala fide harassment action. See also United States v. Long, io F.R.D. 443 (D. Neb. 1950), where a certification was honored with misgivings.

${ }^{88}$ See note ${ }_{13}$ supra.
} 
tion, therefore, both injunctive relief and the means to apply concurrently for state remedial relief may be obtained in the federal courts. After the proxies have been voted, however, only a declaratory judgment as to the validity of the proxies under federal law may be granted. Any affrmative relief after the election must come from the state courts.

The effect which state courts will give a federal decree of proxy invalidity is uncertain. They could accept the decree as res judicata concerning the invalidity of the proxies under state law and turn their attention to determination of the effects of void votes on previous corporate elections and resulting transactions. ${ }^{38}$ The net effect of this reception would be for federal courts to determine the abstract legal question of violation of the proxy fraud rules without regard to the ultimate effect of its decision; while the state courts would face the complex task of determining the effects of the abstract decree. However, it could be argued that res judicata is applicable only to the extent that it invalidates the proxies under federal law. The prohibitions of section $14(a)$ are directed toward proxy solicitation material, and therefore section $29^{40}$ of the act can operate only to invalidate the resulting proxy contract.. Res judicata, by this reasoning, would apply only to establish the fact of federal proxy invalidity, while the deductive process of determining the effect of the judgment would be quite distinct.41

${ }^{30}$ Compare Lyons v. Westinghouse Electric Corp., 222 F.2d I84, 188-89 (2d Cir.), cert. deried, 350 U.S. 825 (1955) (a state court's adjudication that there had been no violation of the federal anti-trust laws was not regarded as res judicata in an action for an accounting on an agency contract), and RESTATEMENT, JUDGMENTs $\$ 7$, comment $c$ (1942) (federal court not bound by incidental determination of a matter by a state court which the federal courts alone have jurisdiction to determine directly) with Kaufman v. Shoenberg, 154 F. Supp. 64 (D. Del. 1954), where plaintiff was denied an injunction for an alleged violation of the federal proxy fraud rules on the basis of a previous state court adjudication of the fraud issue. The federal court held that the issue of fraud was the same, whether federal or state, and it had been conclusively determined against the plaintiff in the state proceedings. See also Sutton v. Leib, 342 U.S. 402 (1952), where the Court held that Illinois must accord full faith and credit to a New York annulment of a Nevada marriage, but left the state court free to determine the effect of such annulment under Illinois law. For the effect of laches, see Hombert v. Armbrecht, 327 U.S. 392 (1946).

${ }^{10}$ See note 3 I supra.

42 "[W] e do not hesitate to hold that ... no fact decided in the first [suit] whether 'ultimate' or a 'mediate 'datum,' conclusively establishes any 'mediate datum' in the second, or anything except a fact 'ultimate' in that suit." The Evergreens v. Numan, 141 F.2d 927, 930-31 (2d Cir.), cert. denied, 323 U.S. 720 (1940); RESTATEMENT, JUDGMENTS $\$ 68$, comment p (1942, Supp. 1948). 
A state court could possibly hold that res judicata would not be applicable in a subsequent petition for restrospective relief. The court in Dann held that it was "without jurisdiction ... to rescind corporate transactions already consummated because of allegedly improperly solicited proxies."142 It could be contended that since res judicata applies only to those issues over which the previous court had jurisdiction, ${ }^{\text {13 }}$ a federal decree of proxy invalidity would be res judicata only as to prospective relief and would not be binding in a petition for retrospective relief.

Thus, there is a likelihood of inconsistent state court application of federal decrees concerning proxy invalidity. To avoid this result, the court could have remanded the case for declaratory judgment only as to violation of the proxy rules and the severity of such violation, thereby allowing the state courts latitude to determine both the invalidity and the subsequent effects. It seems inconsistent that the court should assume jurisdiction to determine the ultimate ground upon which rescission could be granted, e.g., proxy invalidity, while it denies, at the same time, its own jurisdiction to effect such a result. ${ }^{44}$

It is doubtful that the rule in Dann giving the traditional "aggrieved shareholder" a "right" to demand corporate compliance with the statutory sanctions of section $14(a)$ by invocation of pre-election injunction will significantly reduce the injection of misleading information into proxy solicitation material. The average investor is poorly equipped to recognize misleading information in solicitation statements; whereas the SEC, with its facilities and staff of trained personnel, routinely examines the material with professional criticism and expert knowledge of the proxy rules. ${ }^{45}$ However, the new threat of a post-

12288 F.2d at 214 .

${ }^{4}$ Restatement, JuDGMENTS $\S \S 7$, I0, 71. It could also be argued that $\S 27$ of the act, by reserving exclusive federal jurisdiction in "actions brought to enforce any liability or duty created..." precludes state courts from assuming jurisdiction to "enforce" the federal decree. See In re R. Hoe \& Co., 137 N.Y.S.2d 142, 149 (Sup. Ct. 1954), where the court said that "exclusive jurisdiction to grant a remedy for violation .... is in the Federal courts."

"Perhaps the court was concerned with the fact that a determination of a violation of the federal proxy fraud rules might fail to support violation of the "hornbook" deceit laws of some states. Cf. Investment Associates, Inc. v. Standard Power \& Light Corp., 29 Del. Ch. 225, 48 A.2d 501 (Ch. 1946) (rule X-14A-r could have been violated, but still not be grounds for relief under Delaware law). See generally 3 Loss, Securities Regulation I430-44 (2d ed. I961).

${ }^{35}$ Proxy solicitation material must be submitted to the SEC ten days prior to the- 
election civil suit may have a significant prohibitive impact on would-be violators. The magnitude of the threat, of course, depends upon the effect which state courts afford the federal decree of proxy invalidity.

date when copies are to be sent to the shareholders. SEC Reg. 14, 17 C.F.R. \& 240.14a-6 (Supp. 1960). 